\title{
The Role of Contextual Factors in Cyberspace Harm, Anxiety, Aggression, and Students' Academic Performance
}

\author{
Zahra Sadat Aghaei ${ }^{a}\left(\mathbb{D}\right.$, Maryam Kian ${ }^{\text {b* }}$ (iD)
}

${ }^{a}$ Department of Educational Sciences, Yazd University \& School Principal, Yazd, Iran.

${ }^{\mathrm{b}}$ Department of Education, Faculty of Psychology \& Education, Yazd University, Yazd, Iran.

\begin{tabular}{ll}
\hline $\boldsymbol{A} \boldsymbol{R}$ T I C L E I N F O & $\boldsymbol{A} \boldsymbol{B} \boldsymbol{S} \boldsymbol{T} \boldsymbol{R} \boldsymbol{A} \boldsymbol{C} \boldsymbol{T}$ \\
\hline ORIGINAL ARTICLE & $\begin{array}{l}\text { Background: Nowadays, cyberspace has presented both concerns and } \\
\text { interests for the educational researchers. This study aimed to investigate the } \\
\text { role of contextual factors in cyberspace harm, anxiety, aggression, and } \\
\text { academic performance. }\end{array}$
\end{tabular}

Revised: 21 Nov 2020

Accepted: 21 Dec 2020

Methods: A descriptive correlation research method was applied. The research population covered all high school students in Yazd (21,328 students). The number of 377 students were chosen as the sample through a

\section{*Corresponding Author:}

Maryam Kian

\section{Email:}

kian2011@yazd.ac.ir

Tel: +983531232118

\section{Citation:}

Aghaei ZS, Kian M. The role of contextual factors in cyberspace harm, anxiety, aggression, and students' academic performance. Journal of Social Behavior and Community Health (JSBCH). 2021; 5(1): 641-651. stratified sampling based on the Cochran's formula. The research tools included the questionnaires of contextual factors, and the standard scales of cyberspace harm, anxiety, aggression, and academic performance. The validity and reliability of the scales were determined. Data were analyzed by variance, $\mathrm{t}$-test, and Tukey post hoc test.

Results: The findings showed that there are significant differences in cyberspace harm according to some contextual variables such as gender, educational and academic levels, educational district, type of school, field of study, and parents' occupation. More precisely, the harm of cyberspace was more high among the schools of District 2, non-public schools, and the academic field of humanities. Moreover, there was no relationship between the parents' education and the other variables. However, there was a significant relationship between the parents' occupation, regarding the employed mothers, as well as anxiety.

Conclusion: In general, it can be concluded that cyberspace could provide students some challenges as it is affected by various contextual factors. According to the findings, several practical suggestions were presented in the study.

Keywords: Cyberspace, Anxiety, Aggression, Academic Performance, Underlying Factors, Secondary Education 


\section{Introduction}

Today, applying "cyberspace" capabilities has become more comprehensive and extensive among different societies, particularly the adolescent generation, so that its effects can be observed in different aspects of adolescents' lives. "Cyberspace" relates to a space that enables social interactions among diverse cultures through new technologies without considering the dimension of time and place (Morad Haseli \& Manteghi, 2017).

On the other hand, "anxiety" is the most prevalent mental disorder in all age groups and is regarded as a significant factor in the appearance of some social and family problems (Somers et al., 2006). While children and adolescents experience an extended range of anxieties through their development, these anxieties are sometimes so severe that they make their everyday and educational life difficult (Abolghasemi \& Saeedi, 2012). "Aggression" is also considered as one of the adolescents' behavioral characteristics which may show itself in various forms. Hostility reveals the cognitive aspect of aggression, and anger shows its emotional aspect. The behavioral aspect of aggression also takes place in "verbal and physical" forms (Khazaie et al., 2011). However, the effects of applying cyberspace, as well as the mentioned variables, can also affect an individual's "academic performance". Atkinson recognizes academic performance as an individual's learned or acquired ability in school subjects measured by standardized tests (Younesi \& Salehi, 2016).

According to the research, the outstanding point is that being a cyberspace user can influence characteristics such as anxiety, aggression, and academic performance in students. While excessive use of cyberspace raises psychological arousal and restricts physical activity, it can result in physical and mental health problems, including depression, loneliness, and anxiety. Furthermore, inappropriately using cyberspace can interrupt the process of academic works, social life, and other aspects of a person's life, such as adolescent interactions with family (Nainian et al., 2016).
One problem is that communication technologies, particularly cyberspace capabilities, are increasingly getting introduced at homes, and more importantly, the absence of adequate awareness on the part of families can set students at risk more than anything else. One of the hazards of extreme use of cyberspace in students is its adverse effect on their mental health and academic performance causing students to drop out of the educational system. Accordingly, this alarming issue should be considered more than ever in education programs. The question that arises is that what is the role of contextual factors (such as family, school, academic major, etc) in using cyberspace in students, and in the meantime, what is the relationship between these contextual factors and anxiety, aggression, and students' academic performance? These issues have been less discussed among the research conducted in Iran, and this study plans to investigate the answer among high school students in Yazd.

There are some studies conducted outside Iran. For example, Shek et al. (2019) showed that parent's control behavior and maternal psychological control are two simultaneous and long-term predictors of adolescent Internet addiction variables. Kayastha et al. (2018) discovered that Nepalese adolescents are regularly normal Internet users. However, there is a significant relationship between some contextual factors such as age, educational background, and father's occupation, and adolescent Internet addiction and its range. Furthermore, Kilic et al. (2016) stated in their study that male students and single-sex vocational school students described higher levels of Internet addiction. It was recognized that Internet addiction scores are increased by getting students' poor academic performance. On the other hand, this score is decreased in students by increasing the level of family social support and communication skills in students. Luis et al. (2016) also showed that students who repeatedly play video games and engage in unhealthy behaviors have weaker 
academic performance, while students who only play video games have better academic performance. Furthermore, Boo's research (2014) determined that there is a negative correlation between time spent on playing video games and academic performance, as well as between playing time and motivation.

Some studies conducted in Iran. For example, Misaghi et al. (2018) revealed that there is a significant relationship between parental performance and a wide generation gap between children and parents, and adolescents' addiction to social networks. Seraji et al. (2017) also determined that students use virtual social networks to gain new information, entertainment, and interact with others. Additionally, Shoja Kazemi and Shahabi Nejad (2016) stated that there is a significant relationship between playing computer games and students' aggression, as well as between the duration of playing computer games and the intensity of aggression. Kharazani (2016) also revealed that family's role in controlling the tendency to violence and students' membership in groups using the Internet and playing computer games leads them to violence. On the other hand, controlling their use of the Internet and computer games improves their managing violence in this group. Moreover, Hosseini Shirvani et al. (2015) revealed a strong relationship between computer games and academic failure and academic motivation. They discovered a weak relationship between computer games and student learning. Turi et al. (2015) showed that the average Internet addiction, anxiety, and depression in the Internet-addicted students were significantly more crucial than normal users. Also, Zandvanian et al. (2013) showed that extreme use of cyberspace affects the student in the family, education, adjustment, belief-worship, and psychological dimensions. It was further revealed that "cell phones" have the most, whereas "computer games" have the least harm for students among cyberspace devices.

\section{Methods}

\section{A) Method and participants}

This study was a quantitative one, and was conducted using the descriptive-correlational method. The statistical population included all high school students in two educational districts in Yazd (21,328 people), in academic year 2018. The number of 377 people were selected as the research sample through Cochran's formula recognizing the variance of the population.

\section{B) Research instruments}

The research instruments included:

1- The "Contextual factors questionnaire": It included some demographic information about gender, parent's education, parent's occupation, type of school, educational district, educational level, and study field.

2- The "Cyberspace questionnaire" Zandvanian et al. (2013): This questionnaire has been developed to identify the rate of cyberspace injuries and chances in students. This test has five subscales and 30 items. The subscales include students' family, education, religious beliefs, and psychological factors. The method of scoring and interpreting the questionnaire were based on dual grading. The maximum effect was 5 and the minimum was 1 . The Cronbach's alpha method was used to determine the reliability. The alpha value of the Internet item is 0.917 , the computer game is 0.898 , the TV is 0.916 , the satellite is 0.933 , and the cell phone is 0.90 . The tool also has face validity since it was given to ten university professors to confirm the validity.

3- The "Aggression Test" (Zahedifar et al., 2000): A 94-item questionnaire was generated to create a preliminary form of aggression scale. It was presented to two psychologists to determine the face score. The scale was designed such that the subjects should respond to one of the four options: never (0), rarely (1), sometimes (2), and always (3). It was decided to measure the validity of the scale concurrently with three standard scales according to the Scree test (Cattle, 1996) .

4- The "Anxiety Test" (Beck et al., 1988, 
quoted by Fathi Ashtiani, 2009): The questionnaire includes 21 items and is scored in the range of 0 to 63 . Its correlation coefficient (alpha coefficient) is 0.82 , its validity differs from a one-week retest method to 0.75 , and the correlation of its substances varies from 0.30 to 0.76. Five types of content, simultaneous, structural, diagnostic, and factor validity, have been measured for that test.

5- The "Academic Performance Test (APT)" (Adapted from Fam \& Taylor Research, 1999, quoted in Dortaj, 2004): This test has 48 questions. The test is scored on a 5-point Likert scale. After calculating the components, questions related to the components of emotional effects and lack of outcome control should be reversed and then added to the scores of other components to calculate the total academic performance score. This test's content validity was evaluated by the professor's opinions and factor analysis method, and Cronbach's alpha method was used to evaluate the reliability of the test.

\section{C) Data analysis method}

Data were analyzed using descriptive and inferential statistics in the form of t-test, F-test, Tukey test, and variance analysis method in SPSS 21 software. The t-test was used to compare data from different participants' groups and Tukey test was implied for pair comparisons between the groups. In addition, variance analysis waes used for the means comparisons.

This article is registered with the Ethics Code of IR.YAZD.REC.1398.028.

\section{Results}

1- The rate of cyberspace harm, aggression, and poor academic performance in high school students in districts 1 and 2

The hypothesis of equality of the dependent variable variance was accepted for all variables employing the Levin test. In the mean comparison test, the significant value of cyberspace harm variables was less than 0.05 , which confirms the difference of this variable between the students of districts one and two.
Cyberspace harm is more among students in District 2 than District 1. But in other variables, the district does not affect them.

2- The range of cyberspace harm, aggression, and poor academic performance in male and female students

The significance value of cyberspace harm and anxiety variables has been less than 0.05 , which confirms the difference between these two variables among male and female students.

Cyberspace harms males more than females, but anxiety is more in females than males. Other variables do not differ between male and female students.

3-The rate of cyberspace harm, aggression, and poor academic performance in first and second-grade students

The hypothesis of equality of variance of the dependent variable was accepted for all variables using the Levin test. The significance value of all variables was more than 0.05 . The mean comparison test shows that there is no significant difference between the variables among tenth and eleventh-grade students.

4- The range of cyberspace harm, aggression, and poor academic performance in public and non-public school students

The significance value of cyberspace harm and aggression variables has been less than 0.05, which confirms the difference between these two variables among public and non-public school students.

Cyberspace harm and aggression are more among students in non-public schools than in public schools. Other variables do not differ between public and non-public school students.

\section{5- The rate of cyberspace harm, aggression,} and poor academic performance in students of humanities, experimental sciences, mathematics, physics, and vocational training

All variables are significantly different in at least two different disciplines/field studies of students. We use Tukey's test to examine which fields have made a difference in these variables because of the homogeneity of variance. As the 
results of the Tukey test show, students of humanities and experimental sciences are significantly different from each other in terms of cyberspace harm and this harm is more in humanities students. Next, there is a significant difference between students studying in the industrial field and students studying in mathematical physics and humanities in terms of aggression.

6- The relationship between cyberspace harm, anxiety, aggression, and poor academic performance in students, and parents' education

There is no significant difference between the level of father's education and any of the variables. Furthermore, according to the conducted test and the significant value of the test, we conclude that there is no significant relationship between the variables and the mother's education.
7- The relationship between cyberspace harm, anxiety, aggression, and poor academic performance in students, and parents' occupation

There is no relationship between the father's occupation and any of the variables. In the mean comparison test, only the significant value of the anxiety variable has been less than 0.05 , which confirms the difference between students' anxiety and students whose mothers are employees or housewives.

As specified in the tables below, students whose mothers are employees are more anxious than students whose mothers are housewives. Other variables are not significantly different between employee and housewife mothers.

All the above results have been illustrated in the tables below (Tables 1- 8).

Table 1. Demographic Characteristics of the Research Sample

\begin{tabular}{|c|c|c|c|c|c|c|}
\hline \multirow[b]{2}{*}{ District } & \multicolumn{3}{|c|}{ Gender } & \multicolumn{3}{|c|}{ School type } \\
\hline & Girl & Boy & Total & Public & Non-public & Total \\
\hline District 1 & 90 & 94 & 184 & 9 & 1 & 10 \\
\hline District 2 & 104 & 89 & 193 & 9 & 2 & 11 \\
\hline Total & 194 & 183 & 377 & 18 & 3 & 21 \\
\hline
\end{tabular}

\section{Table 2. Results of One-way Variance Analysis}

\begin{tabular}{|c|c|c|c|c|c|c|}
\hline Research variables & & $\begin{array}{c}\text { Sum of } \\
\text { squares }\end{array}$ & $\begin{array}{c}\text { Freedom } \\
\text { degree }\end{array}$ & $\begin{array}{c}\text { Mean of } \\
\text { squares }\end{array}$ & $\begin{array}{c}\text { F-Test } \\
\text { statistics }\end{array}$ & Significant value \\
\hline & Within-group & 6.512 & 4 & 1.628 & 3.527 & 0.008 \\
\hline \multirow[t]{3}{*}{ Cyberspace harm } & Intergroup & 169.390 & 367 & 0.462 & & \\
\hline & Total & 175.902 & 371 & & & \\
\hline & Within-group & 2.873 & 4 & 0.718 & 2.701 & 0.030 \\
\hline \multirow[t]{2}{*}{ Anxiety } & Intergroup & 97.313 & 366 & 0.266 & & \\
\hline & Total & 100.186 & 370 & & & \\
\hline \multirow[t]{4}{*}{ Aggression } & Within-group & 3.828 & 4 & 0.957 & 3.956 & 0.004 \\
\hline & Intergroup & 88.553 & 366 & 0.242 & & \\
\hline & Total & 92.382 & 370 & & & \\
\hline & Within-group & 4.551 & 4 & 1.138 & 6.566 & 0.000 \\
\hline \multirow[t]{2}{*}{ Academic performance } & Intergroup & 63.250 & 365 & 0.173 & & \\
\hline & Total & 67.802 & 369 & & & \\
\hline Research variables & Levin statistics & First freedom d & gree Sec & \multicolumn{2}{|c|}{ Second freedom degree } & Significant value \\
\hline Cyberspace harm & 1.871 & 4 & & \multicolumn{2}{|l|}{367} & 0.115 \\
\hline Anxiety & 0.371 & 4 & \multicolumn{3}{|c|}{366} & 0.829 \\
\hline Aggression & 2.203 & 4 & \multicolumn{3}{|c|}{366} & 0.068 \\
\hline Academic Performance & 2.823 & 4 & \multicolumn{3}{|c|}{365} & 0.052 \\
\hline
\end{tabular}


Table 3. Homogeneity Test of Variance

\begin{tabular}{|c|c|c|c|c|}
\hline \multirow{2}{*}{$\begin{array}{l}\text { Research } \\
\text { variables }\end{array}$} & \multirow{2}{*}{ Field of study } & \multirow{2}{*}{$\mathbf{N}$} & \multicolumn{2}{|c|}{ Subset for alpha $=\mathbf{0 . 0 5}$} \\
\hline & & & 1 & 2 \\
\hline \multirow{5}{*}{ Cyberspace } & Experimental sciences & 121 & 9374.1 & \\
\hline & Industrial school & 34 & 8459.1 & 8459.1 \\
\hline & mathematical physics & 30 & 0506.2 & 0506.2 \\
\hline & Technical and Vocational training & 61 & 7847.2 & 7847.2 \\
\hline & Humanities & 126 & & 2.2054 \\
\hline \multirow{8}{*}{ Anxiety } & Significant & & 058.0 & 2.2054 \\
\hline & Experimental sciences & 121 & 1.6675 & \\
\hline & Industrial school & 34 & 6713.1 & 6713.1 \\
\hline & mathematical physics & 30 & 7225.1 & 7225.1 \\
\hline & Technical and Vocational training & 65 & 8276.1 & 8276.1 \\
\hline & Humanities & 125 & & 8602.1 \\
\hline & Significant & & 313.0 & 112.0 \\
\hline & Experimental sciences & 34 & 0.19848 & \\
\hline \multirow{4}{*}{ Aggression } & Industrial school & 30 & 2011.2 & 2011.2 \\
\hline & mathematical physics & 121 & 2426.2 & 2426.2 \\
\hline & Technical and Vocational training & 61 & & 3376.2 \\
\hline & Humanities & 125 & & 3376.2 \\
\hline \multirow{7}{*}{$\begin{array}{l}\text { Academic } \\
\text { performance }\end{array}$} & Significant & & 59.0 & 0.615 \\
\hline & Experimental sciences & 120 & & 1195.3 \\
\hline & Industrial school & 314 & 7989.2 & \\
\hline & mathematical physics & 61 & 9274.2 & 9274.2 \\
\hline & Technical and Vocational training & 30 & 8044.2 & \\
\hline & Humanities & 125 & 9714.2 & 9714.2 \\
\hline & Significant & & 0.213 & 0.128 \\
\hline
\end{tabular}

\section{Table 4. Results of Tukey Test for the Research Variables}

\begin{tabular}{|c|c|c|c|c|c|c|c|}
\hline \multirow{13}{*}{ 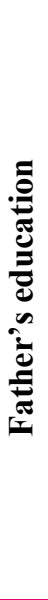 } & $\begin{array}{l}\text { Research } \\
\text { variables }\end{array}$ & & $\begin{array}{l}\text { Sum of } \\
\text { squares }\end{array}$ & $\begin{array}{c}\text { Freedom } \\
\text { degree }\end{array}$ & $\begin{array}{l}\text { Mean of } \\
\text { squares }\end{array}$ & $\begin{array}{c}\text { F-Test } \\
\text { statistics }\end{array}$ & $\begin{array}{c}\text { Significant } \\
\text { value }\end{array}$ \\
\hline & \multirow{3}{*}{ Cyberspace harm } & within-group & 3.563 & 5 & 0.713 & 1.526 & 0.181 \\
\hline & & Intergroup & 169.041 & 362 & 0.467 & & \\
\hline & & Total & 172.604 & 367 & & & \\
\hline & \multirow{3}{*}{ Anxiety } & within-group & 0.354 & 5 & 0.071 & 0.257 & 0.936 \\
\hline & & Intergroup & 99.592 & 361 & 0.276 & & \\
\hline & & Total & 99.946 & 366 & & & \\
\hline & \multirow{3}{*}{ Aggression } & within-group & 0.967 & 5 & 0.193 & 0.779 & 0.565 \\
\hline & & Intergroup & 89.564 & 361 & 0.248 & & \\
\hline & & Total & 90.531 & 366 & & & \\
\hline & \multirow{3}{*}{$\begin{array}{l}\text { Academic } \\
\text { performance }\end{array}$} & within-group & 0.581 & 5 & 0.116 & 0.627 & 0.679 \\
\hline & & Intergroup & 66.789 & 360 & 0.186 & & \\
\hline & & Total & 67.371 & 365 & 0.713 & & \\
\hline
\end{tabular}




\section{Table 5. Results of One-way Variance Analysis (The Relationship Between Parents' Education} and the Research Variables)

\begin{tabular}{|c|c|c|c|c|c|c|c|}
\hline \multirow{13}{*}{ 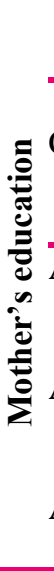 } & Research Variables & & $\begin{array}{l}\text { Sum of } \\
\text { squares }\end{array}$ & $\begin{array}{c}\text { Freedom } \\
\text { degree }\end{array}$ & $\begin{array}{l}\text { Mean of } \\
\text { squares }\end{array}$ & $\begin{array}{c}\text { F-Test } \\
\text { statistics }\end{array}$ & $\begin{array}{c}\text { Significant } \\
\text { value }\end{array}$ \\
\hline & & within-group & 4.573 & 5 & 0.915 & 1.959 & 0.084 \\
\hline & Cyberspace harm & Intergroup & 170.396 & 365 & 0.467 & & \\
\hline & & Total & 174.969 & 370 & & & \\
\hline & & within-group & 687 & 5 & 0.137 & 0.503 & 0.774 \\
\hline & Anxiety & Intergroup & 99.485 & 364 & 0.273 & & \\
\hline & & Total & 100.171 & 369 & & & \\
\hline & & within-group & 1.175 & 5 & 0.235 & 0.946 & 0.451 \\
\hline & Aggression & Intergroup & 90.411 & 364 & 0.248 & & \\
\hline & & Total & 91.586 & 369 & & & \\
\hline & & within-group & .096 & 5 & 0.019 & 0.102 & 0.992 \\
\hline & Academic performance & Intergroup & 68.009 & 363 & 0.187 & & \\
\hline & & Total & 68.104 & 368 & & & \\
\hline
\end{tabular}

\section{Table 6. Levin Test \& Comparison of the Means}

\begin{tabular}{|c|c|c|c|c|c|c|c|c|c|c|}
\hline \multicolumn{2}{|c|}{ Research variables } & \multicolumn{2}{|c|}{$\begin{array}{c}\text { Levin test for } \\
\text { equality of } \\
\text { variances }\end{array}$} & \multicolumn{7}{|c|}{ T-test to compare means } \\
\hline & & \multirow{2}{*}{$\begin{array}{l}\text { F-Test } \\
\text { Statistics }\end{array}$} & \multirow{2}{*}{$\begin{array}{l}\text { Significant } \\
\text { value }\end{array}$} & \multirow{2}{*}{$\begin{array}{l}\text { T-Test } \\
\text { statistics }\end{array}$} & \multirow{2}{*}{\multicolumn{2}{|c|}{$\begin{array}{l}\text { FreedomSignificant } \\
\text { degree value }\end{array}$}} & \multirow{2}{*}{$\begin{array}{l}\text { Mean } \\
\text { difference }\end{array}$} & \multirow{2}{*}{$\begin{array}{c}\text { Error } \\
\text { deviation } \\
\text { for } \\
\text { differences }\end{array}$} & \multicolumn{2}{|c|}{$\begin{array}{l}95 \% \text { Confidence } \\
\text { interval }\end{array}$} \\
\hline & & & & & & & & & $\begin{array}{l}\text { Low } \\
\text { limit }\end{array}$ & $\begin{array}{l}\text { Up } \\
\text { limit }\end{array}$ \\
\hline \multirow{2}{*}{$\begin{array}{l}\text { Cyberspace } \\
\text { harm }\end{array}$} & $\begin{array}{l}\text { Assuming the } \\
\text { equality of } \\
\text { variances }\end{array}$ & 0.753 & 0.386 & 0.531 & 368 & 0.595 & 0.04967 & 0.09348 & -0.13414 & 0.23349 \\
\hline & $\begin{array}{l}\text { Assuming the } \\
\text { inequality of } \\
\text { variances }\end{array}$ & & & 0.520 & 93.262 & 0.604 & 0.04967 & 0.09551 & -0.13997 & 0.23932 \\
\hline \multirow[b]{2}{*}{ Anxiety } & $\begin{array}{l}\text { Assuming the } \\
\text { equality of } \\
\text { variances }\end{array}$ & 1.494 & 0.222 & 1.987 & 367 & 0.048 & 0.14007 & 0.07049 & 0.00146 & 0.27867 \\
\hline & $\begin{array}{l}\text { Assuming the } \\
\text { inequality of } \\
\text { variances }\end{array}$ & & & 1.910 & 91.700 & 0.059 & 0.14007 & 0.07335 & -0.00561 & 0.28575 \\
\hline \multirow[b]{2}{*}{ Aggression } & $\begin{array}{l}\text { Assuming the } \\
\text { equality of } \\
\text { variances }\end{array}$ & 3.466 & 0.063 & 0.346 & 367 & 0.729 & 0.02360 & 0.06813 & -0.11039 & 0.15758 \\
\hline & $\begin{array}{l}\text { Assuming the } \\
\text { inequality of } \\
\text { variances }\end{array}$ & & & 0.313 & 86.833 & 0.755 & 0.02360 & 0.07537 & -0.12622 & 0.17341 \\
\hline Academic & $\begin{array}{l}\text { Assuming the } \\
\text { equality of } \\
\text { variances }\end{array}$ & 1.476 & 0.225 & 0.373 & 366 & 0.710 & 0.02183 & 0.05860 & -0.09341 & 0.13707 \\
\hline pc & $\begin{array}{l}\text { inequality of } \\
\text { variances }\end{array}$ & & & 0.388 & 99.862 & 0.699 & 0.02183 & 0.05629 & -0.08985 & 0.13352 \\
\hline
\end{tabular}




\begin{tabular}{|c|c|c|c|c|c|c|}
\hline Research variables & & $\begin{array}{c}\text { Sum of } \\
\text { squares }\end{array}$ & $\begin{array}{c}\text { Freedom } \\
\text { degree }\end{array}$ & $\begin{array}{l}\text { Mean of } \\
\text { squares }\end{array}$ & $\begin{array}{c}\text { F-Test } \\
\text { statistics }\end{array}$ & $\begin{array}{c}\text { Significant } \\
\text { value }\end{array}$ \\
\hline \multirow{3}{*}{ Cyberspace harm } & Within-group & 1.970 & 4 & 0.492 & 1.042 & 0.386 \\
\hline & Intergroup & 172.082 & 364 & 0.473 & & \\
\hline & Total & 174.052 & 368 & & & \\
\hline \multirow{3}{*}{ Anxiety } & Within-group & 1.903 & 4 & 0.476 & 1.762 & 0.136 \\
\hline & Intergroup & 98.022 & 363 & 0.270 & & \\
\hline & Total & 99.925 & 367 & & & \\
\hline \multirow{3}{*}{ Aggression } & Within-group & 0.245 & 4 & 0.061 & 0.243 & 0.914 \\
\hline & Intergroup & 91.586 & 363 & 0.252 & & \\
\hline & Total & 91.830 & 367 & & & \\
\hline \multirow{3}{*}{ Academic performance } & Within-group & 1.200 & 4 & 0.300 & 1.628 & 0.167 \\
\hline & Intergroup & 66.726 & 362 & 0.184 & & \\
\hline & Total & 67.926 & 366 & & & \\
\hline
\end{tabular}

Table 8. Relationship Between Mother's Employment and Student Anxiety

\begin{tabular}{rlcc}
\multicolumn{1}{c}{ Research variable } & Mother's occupation & Mean & Standard deviation \\
\hline \multirow{2}{*}{ Anxiety } & Employee & 1.8773 & 0.54567 \\
& Housewife & 1.7372 & 0.51295 \\
\hline
\end{tabular}

\section{Discussion}

The results of this study indicated that there are significant differences in the harmfulness of cyberspace in some contextual components such as gender, grade, and field of study, type of school, and parents' occupation. The first finding was that cyberspace's harm in schools in District Two of Yazd is more than District One. We can refer to the issue of socio-economic class differences to explain this finding, which appears to have proved itself in this result. Students in District 2 schools, which are moderately larger and richer, have used greater cyberspace capabilities and have been harmed more. Additionally, another finding showed that cyberspace harm is more in boys than girls, which is consistent with the findings of Azad Majd and Rasooli (2013), Dufour et al. (2016), and Desai \& Sarin. (2010). The results of a study conducted by Dufour et al. (2016) in examining the role of gender to use cyberspace in Canadian high school adolescents determined that boys use cyberspace more than girls, and their use is frequently in the field of Internet computer games. However, girls are more active in social networks. A study conducted by Desai \& Sarin. (2010) also discovered that high school boys who use cyberspace and Internet games experience more stress than female users. We can refer to psychological issues and psychological differences between the two groups to explain this study's findings. Adolescents seem to spend more time in cyberspace. Presumably, the dominant and traditional thinking of families that prefer the boys to spend time on the Internet using their computers or cell phones instead of going out with groups of friends and have fun outside the home can be a factor. However, family monitoring can still be rejected in this type of cyberspace communication.

Another finding showed that there is more anxiety in girls than in boys. This finding is consistent with the findings of the study conducted by Turi et al. (2015) and is inconsistent with the results of the study of Desai \& Sarin (2010). In explaining this finding, it can be noticed that in the Fodor classical view (1974), it is stated that anxiety behavior is consistent with the traditional definition of female roles. Bem (1981) Gender Role Theory declares that girls and boys become social to promote the behaviors, traits, skills, and interests determined in society that are consistent 
with their genders. Because the expression of anxiety is inconsistent with the male gender role, fearful behavior in boys may be less authorized. Furthermore, the behavior of social factors (such as teachers, peers, and the media) may strengthen behaviors consistent with the gender by improving courage among boys and anxiety among girls (Ali Akbari Dehkordi et al., 2013).

Besides, another finding obtained from the present study indicated that cyberspace is more harmful to students in non-public schools. In this view, we can refer to the necessity to concentrate more on educational programs to inform administrators, parents, and students of this type of school about the harms of excessive use of cyberspace.

We observed another finding that revealed cyberspace is more harmful and creates more anxiety for humanities students. Ybarra et al. (2005) consistent with this study, determined that more young people reported more anxiety, they used more Internet in the same way. Thus, it can be explained that social networks can seriously affect the individual's physical and mental health, ranging from insomnia or sleeplessness to aggression and impulsivity, by engaging people with a comprehensive range of pleasant or unpleasant content that is exchanged in these networks.

We achieved another finding that explained there is no relationship between the parents' level of education as well as the father's occupation and any of the variables. This recent finding is consistent with the studies conducted by Turi et al. (2015) and inconsistent with the findings of the study conducted by Kayasta et al. (2018) on the influence of father's occupation on adolescent child Internet addiction. Besides, it was discovered that the significance value of the variable "anxiety" is less than 0.05 , which confirms the difference between students' anxiety and students whose mothers are employees or housewives. Besides, the results pointed out that students whose mothers were employees were more anxious than students whose mothers were housewives. This finding is moderately consistent with the results obtained from the study conducted by Shek et al. (2019) on the role of maternal psychological control over child Internet addiction. Both studies stress the significance of the mother's role in reducing anxiety as well as monitoring the child's application of cyberspace.

\section{Conclusion}

It can be concluded that cyberspace could provide students some challenges as it is affected by various contextual factors. In short, this study gives the following suggestions based on the above findings:

* It seems necessary to study planning and apply expert counselors by schools and parents because cyberspace is more harmful among boys.

*It is recommended to hold more workshops, awareness sessions, and more specialized consultations for the administrators, parents, and students of these schools in the field of cyberspace opportunities and challenges due to the more comprehensive harmfulness of cyberspace among students of non-public schools and schools in District 2 of Yazd.

* The demand to educate and inform adolescents studying in the humanities field about the vulnerabilities of cyberspace and the need to make more fun the educational programs of this group of students are felt more than ever due to the higher harmfulness of cyberspace and more anxiety among humanities students.

* The requirement to decrease the absence of the mother's presence to create a more cohesive emotional relationship between mother and adolescent looks unavoidable given the significant relationship between student "anxiety" and the mother's employment. In this view, training and educational sessions of the Parents and Teachers Association and notifying parents, particularly mothers, can help to solve this problem.

\section{Conflict of interest}

Authors declare no conflict of interest during the study period.

\section{Acknowledgments}

The researchers would like to thank all the 
participants who contributed to the study.

\section{Authors' Contribution}

Conceptualization: M.K.; Methodology: M.K.; Investigation: M.K. and Z.S.A.; Formal analysis: Z.S.A.; Data Curation: Z.S.A.; Writing original draft: M.K and Z.S.A.; Writing, review \& editing: M.K.

All authors read and approved the final manuscript and are responsible for any question related to the article.

\section{References}

Abolghasemi, S., Saeedi, M. (2012). The effectiveness of teaching strategies to deal with stress and Islamic mantra on the level of test anxiety of high school students in Tonekabon. Journal of Religious Psychology, 2(5), 55-66. [Persian]

Ali Akbari Dehkordi, M., Shahriari, H., Zare, M. (2013). Gender, Gender Roles and Anxiety in Zabol School Students. Journal of Educational Psychology Study, 11(20), 117-134. [Persian]

Azad Majd, A., Rasooli, M.R. (2013). Internet addiction and its effects among high school students in Tehran. Social Science Book Monthly, 17(67), 90-97. [Persian]

Bem, S.L. (1981). Bem sex-role inventory. Palo Alto, CA: Consulting Psychologists Press.

Boo, R. (2014). Video game playing, academic performance, educational activity, and motivation among secondary school students. Orebro University School of Business.

Cattell, R. (1996). The scree test for the number of factors. Multivariate Behavioral Research, Vol 1, Issue 2, 245-276.

Desai, R.A., Sarin, S.K. (2010). Video game playing in high school students: health correlates, gender differences and problematic gaming. Journal of Pediatrics, (6)126, 1414-1424.

Dortaj, F. (2004). Academic Performance Questionnaire. Available at: http://farhangdanesh.ir/jangedanesh. [Persian]

Dufour, M., Brunelle, N., Tremblay, J., Leclerc, D., Cousineau, M.M., Khazaal, Y., Légaré, A.A.,
Rousseau, M. Berbiche, D. (2016). Gender Difference in Internet Use and Internet Problems among Quebec High School Students. Canadian Journal of Psychiatry, 61(10), 663-668.

Fathi Ashtiani, A. (2009). Psychological tests, personality assessment and mental health. Tehran: Besat Publications. [Persian]

Hosseini Shirvani, M., Haji Khanian, S., Haji Khanian, S. (2015). The relationship between the use of computer games and the educational status of female high school students in Babol. Journal of Information and Communication Technology, 5(3), 123-137. [Persian]

Kayastha, B., Gurung, A., Chawal, R. (2018). A Descriptive Study to Assess the Level of Internet Addiction among Adolescents: A Case Study of High Schools in Mangalore. Journal Child and Adolescent Behavior, 6(3), 378.

Kharazani, H. (2016). The relationship between cyberspace use and students' tendency to violence. Quarterly Journal of Intelligence and Criminal Research, 11(1), 161-184.

Khazaie, T., Saadatjoo, A., Dormohamadi, S., Soleimani, M., Toosinia, M., Mullah Hassan Zadeh, F. (2011). Prevalence of cell phone dependence and aggression in Birjand adolescents. Scientific Journal of Birjand University of Medical Sciences, 19(4), 430-438.

Kilic, M., Avci, D., Uzuncakmak, T. (2016). Internet Addiction in High School Students in Turkey and Multivariate Analyses of the Underlying Factors. Journal of Addictions Nursing, 27(1), 39-46.

Luis, C., Marilyn Nales, T., Ana Rodriguez, Z. (2016). The Relationship between Videogame Use, Deviant Behavior, and Academic Achievement among a Nationally Representative Sample of High School Seniors in the United States. American Journal of Educational Research, 16(4), 1157-1163.

Misaghi, E., Sadipour, E., Delavar, A., Dortaj, F., Motamedi Shalamzari, A. (2018). The role of family functioning and generation gap in the relationship between parental controls style and addiction to social networks. Iranian journal of 
educational Sociology, 10(8), 1-15. [Persian]

Morad Haseli, M., Manteghi, M. (2017). Identifying the processes related to the development of body image in female adolescents using cyberspace in Iran. Quarterly Journal of Mental Health Research, 11(3), 62-83. [Persian]

Nainian, M.R., et al. (2016). Internet Use and Its Relationship with Mental Health and Quality of Life in High School Students, Bi-Quarterly Journal of Clinical Psychology and Personality, 14(2), 103-113. [Persian]

Seraji, F., Sharifi Rahnmo, S., Habibzadeh A. (2017). Motivations for high school students to use virtual social networks. Journal of Culture and Communication Studies, 4(39), 183-205. [Persian]

Shek, D., Zhu, X., Dou, D. (2019). Influence of Family Processes on Internet Addiction among Late Adolescents in Hong Kong. Frontiers in Psychiatry, 10(113), 1-17.

Shoja Kazemi, M.A., Shahabi Nejad, Z. (2016). Comparison of the use of computer games and aggression in middle school male students in Tehran. Journal of Community Health Education, 3(3), 24-29. [Persian]

Somers, J. M., Goldner, E. M., Waraich, P., Hsu, L. (2006). Prevalence and incidence studies of anxiety disorders: a systematic review of the literature. Canadian Journal of Psychiatry, 51(2), 100-113.

Turi, A., Miri, M., Beheshti, D., Yari, E.,
Khodabakhshi, H., Anani Sarab, G. (2015). Prevalence of Internet addiction and its relationship with anxiety, stress, and depression in intermediate students in Birjand city in 2014. Journal of Birjand University of Medical Sciences, 22(1), 67-75.

Yazd Khasti, B., Alipour, S., Kikhai, E. (2013). Public domain and social network chat (examining the impact of virtual networks on intercultural dialogue). Journal of Culture and Communication Studies, 4(21), 81-110. [Persian]

Ybarra, M.L, Alexander, C., Mitchell, K.J. (2005). Depressive symptomatology, youth Internet use, and online interactions: A national survey. Journal of Adolescent Health, 36(1), 9-18.

Younesi, M.J., Salehi, M. (2016). Relationship between personality traits and self-regulated learning with academic performance of high school students in Eghlid. Journal of Mental Health Principles, 18, 513-519.

Zahedifar, S., Najarian, B., Shokrkon, H. (2000). Design and validation of a scale to measure aggression. Journal of Educational Sciences and Psychology, Shahid Chamran University of Ahvaz, 30(8), 73-102. [Persian]

Zandvanian, A., Heydari, M., Bagheri, R., Attarzadeh, M. (2013). Cyberspace challenges among female students. Journal of Culture and Communication Studies, 4(23), 195-216. [Persian] 